\title{
Sphingosine 1-Phosphate Receptor 2
}

National Cancer Institute

\section{Source}

National Cancer Institute. Sphingosine 1-Phosphate Receptor 2. NCI Thesaurus. Code C104775.

Sphing osine 1-phosphate receptor 2 (353 aa, $\sim 39 \mathrm{kDa}$ ) is encoded by the human S1PR2 gene. This protein is involved in transcriptional activation, cell proliferation and cell survival. 